\title{
Role of Firm Characteristics \& Corporate Governance Mechanism on Type of Earning Smoothing
}

\author{
Hamidreza Kordlouie (Corresponding author) \\ Department of Management, International Qeshm Branch \\ Islamic Azad University, Qeshm Island, Iran \\ Tel: 98-935-2200Ｅ-mail: hamidreza.kordlouie@gmail.com
}

\author{
Azim Sheikhbeglo \\ Department of Accounting, International Qeshm Branch \\ Islamic Azad University, Eslamshahr Branch, Iran \\ Tel: 98-919-234-4615 E-mail: elman.eltan@yahoo.com
}

Received: December 30, 2011

Accepted: March 15, 2012 Published: April 16, 2012

doi:10.5539/ijbm.v7n8p71

URL: http://dx.doi.org/10.5539/ijbm.v7n8p71

\begin{abstract}
In order to measure earning smoothing, it is used from discretionary accrual which is regarded as index of management judgment in applying earning smoothing procedures. Pattern for determining discretionary accrual is Dechow and Richardson pattern; therefore, 56 active companies at Tehran stock exchange during time period 2002-2007 were selected based on separating method. In order to determine discretionary accrual it is used from data arrangement on integration basis and regression pattern by using OLS method. Then in order to mention effect of size, number of employees, financial risk and structure of ownership as corporate governance mechanism, it is used from test of comparing averages of 2 independent universes as 2 continued forms. Results of this test indicates effectiveness of size, financial risk and lack of effectiveness of structure of ownership including institutional and block shareholder on type of earning smoothing at $95 \%$ certainty. In addition, effect of number of employees on type of earning smoothing is confirmed at $90 \%$.
\end{abstract}

Keywords: Positive earning smoothing, Negative earning smoothing, Discretionary accruals, Dechow and Richardson pattern, Firm characteristic

\section{Introduction}

Job security of managers is considerably depends on increasing wealth of shareholders. Increasing wealth which means increasing price is function of current and past earning of companies; therefore, if your company has poor performance, it is unexpected to increase price of stock market (Izadinia, 1988) and finally increases possibility of changing managers. Thus, managers having poor performance during a financial period, prefer to manipulate reported earning (Dastgir, 2007). In fact earning smoothing is intentional balance of management at reported earning that is regarded as ordinary event during several fiscal periods of companies (Atik, 2009). Tools that are used for earning smoothing are divided into artificial and real tools. Artificial smoothing is management manipulation for earning smoothing and real smoothing is activities of management for controlling fundamental economic events (Noravesh, 2005). Difference of earning and cash obtained from operation is recognized as discretionary accruals that are divided into optional and non-optional discretionary accruals. Non-optional discretionary accruals are limited by rules, regulations, organizations and other foreign factors and optional discretionary accruals are supervised by management. Therefore, optional discretionary accruals are regarded as index in the way of discovering earning management at accounting studies for commercial units [4]. Previous researches indicated that finance is very effective on performance of company (Moses, 1987). Naturally changing financial risk results in changing performance (earning) of companies. Company managers due to increasing their debits; attempt to smooth their earning. One of reasons of smoothing is precautionary and opportunist approach. In precautionary approach, managers due to increasing the debits shall fulfill their future obligations as a result of concluding debit contract. Distributing earning among owners results in weakening ability of company to pay future earning; therefore, by using this approach and increasing financial risk of 
company, it is expected to have negative earning smoothing. On the other hand by using opportunist approach, managers upon increasing their debits intend to perform positive earning smoothing in order to cover future possible inability; which transmit optimistic message which shows ability of company to fulfill its commitments. Within this message they repeatedly increase their debits and this type of companies are at growing stage. According to previous researches, size of company has negative relationship with stock efficiency and profitability. Based on hypothesis of political costs, companies by increasing their capital transmit message to governments and other rivals. Governments regard this received message as ability of company and by enacting tax, attempt to obtain their excellent rights. Therefore by increasing size of company its supervision costs may also increase. On the other hand, by announcing great size of company, rivals attempt to control operation and its strategies; therefore, it is possible to have effective single activity of companies is under pressure of governments and rivals. It is expected that managers of desired companies by having negative earning smoothing, to postpone current earning to future and therefore there will be more situation for resistance against pressure of governments and rivals. One of the effective factors on type of smoothing divided earning is number of employees (Onder, 2000). Companies having higher number of employees may have higher demand for compensating diverse service; therefore, managers for keeping efficiency at one hand and keeping motivation of human workforce on the other hand, require offering enough and logical evidences. Fiscal reports gone under audit are regarded as suitable basics for showing performance of different fiscal periods. It is expected that these companies by having great number of employees, to perform negative earning smoothing so that no to lose future growth opportunities; meanwhile, by poor performance of managers for keeping hope of their employees and creating suitable profitability, it is required to perform positive earning smoothing. Another effective factor on type of smoothing (Siregar, 2008), is role of owners; in fact owners are among outer mechanisms of corporate governance. Concentrating on structure of ownership shows that owners have same opinion for administering company. If structure of ownership of companies has high concentration, role of block shareholders will be very considerable. Block shareholders due to having higher privilege in making decision, attempt to direct company toward their desired goals. If future goals with profitability projects are observed by block shareholders, they attempt that by using hypothesis of applying pressure to managers to prevent from dividing earning among other owners. Under this condition, goals of block shareholders are the same as management; therefore, managers perform negative earning smoothing. By having this inference, block shareholders in case of not having future profitability projects, may recommend positive earning smoothing to managers. Another type of owners of earning smoothing, are institutional owners. According to supervision hypothesis, institutional owners due to having scientific and financial ability; may have continuous and active supervision. Inference of effect of institutional owners on type of earning smoothing is the same as effect of block shareholders.

\section{Research Background}

\subsection{Worldwide Researches}

Hepworth (1953) has referred to different motivations for earning smoothing and accounting techniques. Belkaoui and Picur (1984) investigate on 171 companies in 42 industries. This study tests the effects of the dual economy on income smoothing behavior. It is hypothesized that a higher degree of smoothing of income numbers will be exhibited by firms in the periphery sector than by firms in the core sector as a reaction to different opportunity structures and experiences. The results indicate that a majority of firms may be resorting to income smoothing. A higher number is included among firms in the periphery sector. Ronen and Sadan (1975) as a result of their research show that forecasting the cash flows according to smoothing income is preferred in comparison to real Incomes which the sudden items are included. They also believe that management smoothes income in order to enhance investors to predict future cash flows. A research has been carried on by Ashari et al. (1994) in which the factors affecting income smoothing are listed. Demski et al. (1999) have done a research on the subject of manipulation, according to their results, managers do income smoothing when a. there is some ethical problem, b. there is informational asymmetric. Another study by Kanagaretnam et al. (2001) show that when banks have suitable current performance and estimate bad future performance, keep some profit for later. Wang and Williams (1994) in disagreement with this point of view that earning smoothing results in deceive, mentioned that earning smoothing results in increasing value of information for accounting profit. In his studies he obtained some evidences which shows that smoothed earnings with respect to market are suitable and companies that their earning is smoothed, may have lower risk. Beidleman (1973) concluded through his research that stock owners usually like to invest in companies which they have smooth earning, because it is a sign of stability of the company. Lev and Nissim (2004) study on the accruals anomaly, they show that the accruals anomaly persists and will probably endure. Lai and Gul (2008) studied on the topic of quality of auditing. In this study, they examine whether the audit quality of L\&H was lower than other auditors. Results do 
not show that $\mathrm{L} \& \mathrm{H}$ is associated with lower quality audits either in terms of lower likelihood of issuing modified audit opinion, higher levels of discretionary accruals for its clients, or lower predictability of discretionary accruals for future non-discretionary net income for its clients than for clients of other auditors. Results of additional tests also do not suggest that auditors that take up clients of L\&H report differently from L\&H. This evidence does not support the proposition that L\&H's audit quality was less than audit quality of other audit firms during the period leading up to the bankruptcy. Huang et al. (2009) studied potential effects of artificial smoothing and real smoothing on value of company and concluded that non-ordinary discretionary accruals has inverse effect on value of companies and by using real smoothing, value of company may increase. Chung et al. (2009) concluded that companies by increasing earning management may suffer less from liquidity of low assets which increases asymmetric information by and between managers and owners. Researches of Hadani et al. (2011) showed that number resolution of shareholders for being executed by managers has negative relationship with future earning management of company and also supervision by institutional shareholders has negative relationship with earning management. Cazavan Jeny et al. (2011) concluded that companies having capital costs related to research and development, may have less current cost related to research and development and therefore they are smaller and has higher ratio of debit to asset to other companies that spent cost for research and development. Nwaeze (2011) confirmed that earning reaction coefficient for companies with higher disclosure of earning management is significantly lower; in addition effect of motivation of disclosure on cash flow has negative significant relationship with discretionary accruals.

\subsection{Domestic Research}

Badri (1999) in his research with title of identifying effective factors on earning smoothing, showed that some factors including size of company, profitability, type of industry, type of ownership and type of company (with respect to covering or non-covering regulations of pricing product) are not regarded as effective factors on earning smoothing. Mashayekhi et al. (2005) concluded that management acts in the way of compensating decrease of cash as a result of operation that indicates poor performance of commercial unit and may increase optional discretionary accruals. Mehrani and Bagheri (2009) inferred that there is direct significant relationship by and between earning management and free cash flow in companies with low growth; however, there was no significant relationship between earning management and institutional shareholders in companies with high free cash flow and low growth.

\section{Research Data, Sample \& Statistical Population}

Data used in the present research are real and historic that is collected from Rahavar Novin software and financial statements of sample companies. Research variables are calculated by Excel spreadsheet and results are used as input of SPSS software; in which statistical analysis were performed by this software. Due to broadness of statistical universe and some disarrangement among members of universe, the following conditions were observed for selecting statistical sample and therefore statistical sample was selected through systematic elimination (separation) method.

1) Fiscal year of companies end to Mar.20 of each year

2) Fiscal year of companies shall not be changed during year 2007-2009

3) Companies shall be active at Tehran stock exchange until end of fiscal year 1999

4) Transaction for stock of companies shall not be stop more than 1 month

5) Financial information of sample companies shall be accessible

According to aforesaid terms and conditions of sampling active companies in Tehran stock exchange until end of year 1999, 56 companies were selected as statistical sample. Time period of this research belongs to year 2002 until 2007; in which, information of these years were used for estimating parameters of Dechow and Richardson (period of event) and from information of year 1999 until 2002, to calculate optional and non-optional variables of discretionary accruals (period of estimation).

\section{Research Hypothesis}

$1^{\text {st }}$ Hypothesis: There is significant difference between number of employees of positive and negative smoothing companies

$2^{\text {nd }}$ Hypothesis: There is significant difference between institutional shareholder of positive and negative smoothing companies

$3^{\text {rd }}$ Hypothesis: There is significant difference between block shareholder of positive and negative smoothing companies 
$4^{\text {th }}$ Hypothesis: There is significant difference between finance of positive and negative smoothing companies

$5^{\text {th }}$ Hypothesis: There is significant difference between size of positive and negative smoothing companies

\section{Research Methodology}

This research with respect to its goal is regarded as applied research that is based on analyzing information collected from archive of Tehran stock exchange. Whereas variables and their effect on each other was studied during all stages of research, therefore this research is regarded as empirical or quasi-empirical research and with respect to research methodology, it is regarded as field research with having post-event based on previous information and observed data of test. In order to test hypothesis it is used from comparing average of 2 universes. The first universe shows company having positive earning smoothing and zero universe shows company having negative earning smoothing.

\subsection{Dependant Variable- Earning Smoothing}

A fundamental factor on earning smoothing test of company is estimating option and comment of managers for determining earning. Studying literature based on earning smoothing, shows different approach with different identification in estimating and measuring options of management for determining earning of report. One of the most important approaches is application of optional discretionary accruals that is regarded as index for determining and discovering earning smoothing at commercial units. Therefore the present research uses from Dechow and Richardson (2002) pattern for studying earning smoothing behavior for companies accepted at Tehran stock exchange. In this pattern, first of all equation (1) for each year from 1999 until 2007 was executed and its coefficients were used for equation (2).

$$
\begin{gathered}
\frac{\Delta R E C_{i t}}{T A_{i t-1}}=\alpha_{0}+k \frac{\Delta R E V_{i t}}{T A_{i t-1}}+\varepsilon_{i t} \\
\frac{A C C R_{i t}}{T A_{i t-1}}=\alpha_{0}+\alpha_{1}\left[\frac{\Delta R E V_{i t}}{T A_{i t-1}}-(1-k) \frac{\Delta R E C_{i t}}{T A_{i t-1}}\right]+\alpha_{2} \frac{P P E_{i t}}{T A_{i t-1}}+\alpha_{3} \frac{A C C R_{i t}}{T A_{i t-1}}+\alpha_{4} \frac{\Delta R E V_{i t}}{T A_{i t-1}}+\varepsilon_{i t}
\end{gathered}
$$

Then we used from pattern (2) for 3 years ago and estimated coefficients of second model were multiplied at real values of pattern (3) of each year, to obtain NDAC for each year:

$$
N A D A C_{i t}=\hat{a}_{0}+\hat{a}_{1}\left[\frac{\Delta R E V_{i t}}{T A_{i t-1}}-(1-k) \frac{\Delta R E C_{i t}}{T A_{i t-1}}\right]+\hat{a}_{2} \frac{P P E_{i t}}{T A_{i t-1}}+\hat{a}_{3} \frac{A C C R_{i t}}{T A_{i t-1}}+\hat{a}_{4} \frac{\Delta R E V_{i t}}{T A_{i t-1}}
$$

Finally discretionary accrual is obtained as follows:

$$
D A C_{i t}=\frac{A C C R_{i t}}{T A_{i t-1}}-N A D A C_{i t}
$$

\section{Research Findings}

\subsection{Descriptive Statistics}

Among total 336 active companies at Tehran stock exchange, there were 141 companies with negative smoothing and 195 companies with positive smoothing. Table 1 shows statistical quantity of required variables for calculating earning smoothing index and table 2 shows statistical quantity of companies with negative smoothing and table 3 shows companies with positive smoothing.

\subsection{Results of Hypothesis Test}

\subsection{1 $1^{\text {st }}$ Hypothesis}

There is significant difference between number of employees of positive and negative earning smoothing companies. Results are shown in Tables 4 and 5.

$\mu 1=$ Average number of employees of negative earning smoothing companies

$\mu 2=$ Average number of employees of positive earning smoothing companies

As it is observed in Tables 4 and 5, there are 195 companies with positive earning smoothing and 141 companies with negative earning smoothing; in which, possibility of test (P-value) is less than $5 \%(0.034<5 \%)$, therefore by $95 \%$ certainty it is possible to say that hypothesis in relation to equality of variance is rejected. Whereas significance level of not equality of variance is more than $5 \%$, it is possible to say that hypothesis in relation to equality of averages of both universes is accepted and its opposite hypothesis i.e. not equality of both averages is 
rejected; therefore, first hypothesis is rejected $(0.089>5 \%)$; meanwhile, at $90 \%$ certainty results of testing first hypothesis is accepted.

\subsection{2 $2^{\text {nd }}$ Hypothesis}

There is significant difference between structure of ownership (institutional shareholder) and positive and negative earning smoothing companies. Results are shown in Tables 6 and 7.

$\mu 1=$ Average percentage of ownership of institutional shareholders at negative earning smoothing companies

$\mu 2=$ Average percentage of ownership of institutional shareholders at positive earning smoothing companies

As it is observed in Tables 6 and 7, possibility of test (P-value) is greater than 5\% $(0.21>5 \%)$; therefore by 95\% certainty it is possible to say that hypothesis in relation to equality of variance is accepted. Whereas significance level of equality of variance is more than $5 \%$, it is possible to say that hypothesis in relation to equality of averages of both universes is accepted therefore, second hypothesis concerning that there is significant difference between structure of ownership (institutional shareholder) of negative and positive earning smoothing companies, is rejected $(0.19>5 \%)$.

\subsection{3 $3^{\text {rd }}$ Hypothesis}

There is significant difference between structure of ownership (block shareholder) and positive and negative earning smoothing companies. Results are shown in Tables 8 and 9.

$\mu 1=$ Average percentage of ownership of block shareholders at negative earning smoothing companies

$\mu 2=$ Average percentage of ownership of block shareholders at positive earning smoothing companies

As it is observed in Tables 8 and 9, possibility of test (P-value) is greater than $5 \%(0.431>5 \%)$ therefore by $95 \%$ certainty it is possible to say that hypothesis in relation to equality of variance is accepted. Whereas significance level of equality of variance is more than $5 \%$, it is possible to say that hypothesis in relation to equality of averages of both universes is accepted; therefore, second hypothesis concerning that there is significant difference between structure of ownership (block shareholder) of negative and positive earning smoothing companies, is rejected $(5 \%<0.159)$.

\subsection{4 $4^{\text {th }}$ Hypothesis}

There is significant difference between total ratio of debit to assets of positive and negative earning smoothing companies. Results are shown in Tables 10 and 11.

$\mu 1=$ Average percentage of total ratio of debit to assets of negative earning smoothing companies

$\mu 2=$ Average percentage of total ratio of debit to assets of positive earning smoothing companies

As it is observed in Tables 10 and 11, possibility of test (P-value) is less than 5\% $(0.008<5 \%)$; therefore by $95 \%$ certainty it is possible to say that hypothesis in relation to equality of variance is rejected. Whereas significance level of equality of variance is less than $5 \%$, it is possible to say that hypothesis in relation to equality of averages of both universes is rejected; therefore, fourth hypothesis concerning that there is significant difference between total ratio of debit to assets of negative and positive earning smoothing companies, is accepted $(0.035<5 \%)$.

\subsection{5 $5^{\text {th }}$ Hypothesis}

There is significant difference size of positive and negative earning smoothing companies. Results are shown in Tables 12 and 13.

$\mu 1=$ Average size of negative earning smoothing companies

$\mu 2=$ Average size of positive earning smoothing companies

As it is observed in Tables 12 and 13, possibility of test (P-value) is greater than 5\% (0.309>5\%); therefore by $95 \%$ certainty it is possible to say that hypothesis in relation to equality of variance is accepted. Whereas significance level of equality of variance is less than $5 \%$, it is possible to say that hypothesis in relation to equality of averages of both universes is rejected; therefore, fifth hypothesis concerning that there is significant difference between size of negative and positive earning smoothing companies, is accepted $(5 \%>0.001)$.

\section{Conclusion \& Suggestion}

Results of first hypothesis shows that in compatibility with studies of Hepworth (1953), companies having higher number of employees may use from negative earning smoothing i.e. since such companies have higher demand for compensating diversity of services; therefore, they use negative earning smoothing in order not to 
lose future growth opportunities. On the other hand, companies with less number of employees, may use from positive earning smoothing in order to keep their employees and creating job security for them. Results of second and third hypothesis shows that structure of ownership does not influence on type of earning smoothing; therefore, it is possible to conclude that owners (institutional and block) as outer mechanisms of company, may not direct managers for not distributing earning for possible future earning making opportunities and distributing earning when there is no future earning making opportunity. Results of the first hypothesis that is compatible with research of Trueman and Titman (1988) confirms opportunistic approach for Iranian managers and rejects precautionary approach for distributing earning among owners. Therefore, managers by increasing their debit may transmit message to creditors in relation to ability of company for paying debits and they obtain opportunity for repeated increase of their debit. Results of fifth hypothesis shows that great size companies may use negative earning smoothing; therefore, according to political hypothesis the great size companies for preventing from increasing their demand from government and preventing action of their rivals, may report less earning in their annual report; in which, this result is compatible with study of Moses (1987). According results of research and possibility of manipulation approach at poor financial market, it is recommended that Tehran stock exchange and investors shall announce their discretionary accruals to optional disclosure of their information. Investors while making investment and persons offering fund while allocating budget shall carefully attention to earning smoothing and do not regard this issue as the only symbol of stability of company. By performing any scientific study, a new door is open toward new path and continuing this path requires conducting more research in this field. It is necessary to conduct more research in relation to following topics:

1) Studying effect of commercial risk on type of earning smoothing;

2) Studying effect of type of industry on type of earning smoothing.

\section{References}

Ashari, N., Koh, H. C., Tan, S. L., \& Wong, W. H. (1994). Factors affecting income smoothing among listed companies in Singapore. Accounting and business research, 24(96), 291-301.

Atik, A. (2009). Detecting income-smoothing behaviours of Turkish listed companies through empirical tests using discretionary accounting changes. Critical perspectives on accounting, 20, 591-613. http://dx.doi.org/10.1016/j.cpa.2008.01.003

Badri, A. (1999). Identifying the effective factors on earning smoothing at Tehran stock market. $\mathrm{PhD}$ thesis.

Beidleman, C. (1973). Income Smoothing: The role of management. The Accounting Review, 48(4), 653-667.

Belkaoui A., \& Picur, R. D. (1984). The smoothing of income numbers: some empirical evidence on systematic difference between core and periphery industrial sectors. Journal of Business Finance and Accounting, 11(4), 527-45. http://dx.doi.org/10.1111/j.1468-5957.1984.tb00768.x

Cazavan-Jeny, A., Jeanjean, T., \& Joos, P. (2011). Accounting choice and future performance: The case of R\&D accounting in France. Journal of accounting and public policy, 30(2), 145-165. http://dx.doi.org/10.1016/j.jaccpubpol.2010.09.016

Chung, H., Sheu, H. J., \& Wang, J. L. (2009). Do firms earnings management practices affect their equity liquidity. Finance research letters, 6(3), 152-158. http://dx.doi.org/10.1016/j.frl.2009.03.003

Dastgir, M., \& Soleimanian, Gh. (2007). Forged accounting (comparative approach). Formal accountant.

Dechow, P. M., Richardson, S., \& Tuna, A. I. (2003). Earnings management and costs to investors from firms meeting or slightly exceeding benchmarks, Working Paper (University of Michigan Business School).

Demski, J. S., \& Frimor, H. (1999). Performance measure garbling under renegotiation in multi-period agencies. Journal of Accounting Research, 37, 187-214. http://dx.doi.org/10.2307/2491353

Hadani, M., Goranova, M., \& Khan, R. (2011). Institutional investors, shareholder activism, and earnings management. Journal of business research, 64(12), 1352-1360. http://dx.doi.org/10.1016/j.jbusres.2010.12.004

Hepworth, S. R. (1953). Smoothing periodic income. The accounting review, 28(1), 9-32.

Huang, P., Zhang, Y., Deis, D., \& Moffitt, J. (2009). Do artificial income smoothing and real income smoothing contribute to firm value eauivalently?. Journal of Banking \& Finance, 33, 224-233. http://dx.doi.org/10.1016/j.jbankfin.2008.07.012

Izadinia, N. (1988). The effect of financial disclosure policies on stock price. Accounting and auditing investigations, 22, 112-130. 
Kanagaretnam, K., Lobo, G. J., \& Mathieu, R. (2001). Managerial Incentives for Income Smoothing through Bank Loan Loss Provisions. [Online] Available: www.ssrn.com

Lai, K. W., \& Gul, F. A. (2008). Was audit quality of Laventhol and Horwath poor?. Journal of accounting and public policy, 27(3), 217-237. http://dx.doi.org/10.1016/j.jaccpubpol.2008.02.002

Lev, B., \& Nissim, D. (2004). The persistence of the accruals anomaly, Working Paper (New York University. No. 2451/27466).

Mashayekhi, B., Mehrani, S., Mehrani, K., \& Karami, Gh. (2005). The role of discretionary accrual on earning management, (case study: Tehran Stock Market). Accounting and auditing investigations, 42, 61-74.

Mehrani, S., \& Bagheri, B. (2009). Surveying the effect of free cash flows and institutional stock holders on earning management (case study: Tehran stock market). Accounting investigations, 2, 50-71.

Moses, O. D. (1987). Income smoothing and incentives: Empirical tests using accounting changes. The accounting review, 11(2), 358-77.

Noravesh, I., \& Siasi, S. (2005). Surveying the relationship between cultural value and earning smoothing (case: Firms at Tehran Stock exchange). Accounting and auditing investigations, 40, 84-96.

Nwaeze, E. T. (2011). Are incentives for earnings management reflected in the ERC: Large sample evidence. Advances in accounting, incorporating advances in international accounting, 27(1), 26-38.

Onder, Z. (2000). I'MKB'deki Tu“'rk S, irketlerinde Mu'lkiyet Yapısı ve S, irketlerin Performansına Etkileri. Muhasebe Bilim D"unyası Dergisi, 2(2), 51-68.

Ronen, J., \& Sadan, S. (1981). Smoothing Income Numbers: Objectives means, and implications. Addison-Wesley Publishing Company.

Siregar, S. V., \& Utama, S. (2008). Type of earnings management and the effect of ownership structure, firm size, and corporate-governance practices: Evidence from Indonesia. The international journal of accounting, 43(1), 1-27. http://dx.doi.org/10.1016/j.intacc.2008.01.001

Trueman, B., \& Titman, Sh. (1988). An explanation for accounting income smoothing. Journal of accounting research, 26, 127-139. http://dx.doi.org/10.2307/2491184

Wang, Z., \& Williams, T. H. (1994). Accounting income smoothing and stockholders wealth. Journal of applied business research, 10(3), 96-104.

Table 1. Descriptive statistics of variables used for assessing index of earning smoothing

\begin{tabular}{|c|c|c|c|c|c|c|}
\hline \multirow{2}{*}{ Variables } & \multicolumn{7}{|c|}{ Total sample } \\
\cline { 2 - 7 } & Average & Mean & Standard deviation & Maximum & Minimum & No \\
\hline Size & 5,73 & -13486623.74 & 0.62 & 7.75 & 4.43 & 336 \\
\hline TD/TA & 0.09 & 0.06 & 0.10 & 0.38 & 0.00 & 336 \\
\hline Inst share & 23.38 & 23.52 & 3606.07 & 92.20 & 0.00 & 336 \\
\hline Major share & 46.46 & 48.22 & 18.65 & 92.20 & 0.00 & 336 \\
\hline Noemp & 1317.62 & 640.00 & 2844.07 & 19002.00 & 32.00 & 336 \\
\hline
\end{tabular}

Table 2. Descriptive statistics of variables earning smoothing

\begin{tabular}{|c|c|c|c|c|c|c|}
\hline \multirow{2}{*}{ Variables } & \multicolumn{7}{|c|}{ Total sample } \\
\cline { 2 - 7 } & Average & Mean & Standard deviation & Maximum & Minimum & No \\
\hline Size & 5.735 & 5.635 & 0.571 & 7.559 & 4.540 & 141 \\
\hline TD/TA & 0.084 & 0.051 & 0.090 & 0.559 & 0.000 & 141 \\
\hline Inst share & 36.026 & 24.360 & 30.871 & 96.770 & 0.000 & 141 \\
\hline Major share & 48.152 & 49.000 & 18.831 & 92.490 & 13.210 & 141 \\
\hline Noemp & 1095.709 & 613.000 & 1958.108 & 18648.000 & 33.000 & 141 \\
\hline
\end{tabular}


Table 3. Descriptive statistics for positive earning smoothing companies

\begin{tabular}{|c|c|c|c|c|c|c|}
\hline \multirow{2}{*}{ Variables } & \multicolumn{5}{|c|}{ Total sample } \\
\cline { 2 - 7 } & Average & Mean & Standard deviation & Maximum & Minimum & No \\
\hline Size & 5.729 & 5.603 & 0.647 & 7.845 & 4.434 & 195 \\
\hline TD/TA & 0.099 & 0.062 & 0.105 & 0.650 & 0.002 & 195 \\
\hline Inst share & 369.910 & 22.460 & 47.265 & 66.033 & 0.000 & 195 \\
\hline Major share & 45.239 & 47.000 & 18.467 & 92.200 & 0.070 & 195 \\
\hline Noemp & 1478.071 & 685.000 & 3337.524 & 21346.000 & 32.000 & 195 \\
\hline
\end{tabular}

Table 4. Results of first hypothesis test

\begin{tabular}{|l|l|l|l|l|l|}
\hline Std error mean & Std deviation & Mean & N & Smooth & \\
\hline 239.0050872 & 3337.5244 & 1478.072 & 195 & 1 & NOEMP \\
\hline 164.9024828 & 1958.1085 & 1095.709 & 195 & 0 & \\
\hline
\end{tabular}

Table 5. Results of first hypothesis test

\begin{tabular}{|c|c|c|c|c|c|c|c|c|c|}
\hline \multicolumn{5}{|c|}{ T-test for equality of means } & \multicolumn{2}{|c|}{$\begin{array}{c}\text { Variance } \\
\text { equality test }\end{array}$} & NOEMP \\
\hline $\begin{array}{c}95 \% \text { confidence interval of } \\
\text { the difference }\end{array}$ & $\begin{array}{c}\text { Std error } \\
\text { difference }\end{array}$ & $\begin{array}{c}\text { Mean } \\
\text { difference }\end{array}$ & Sig & df & $\mathrm{t}$ & sig & $\mathrm{f}$ & \\
\hline 1000.3738 & -235.6486092 & 314.1750339 & 382.362575 & 0.224 & 334 & 1.217 & 0.034 & 4.549 & $\begin{array}{c}\text { Equality of } \\
\text { variance }\end{array}$ \\
\hline 953.6319389 & -188.9067888 & 290.3726236 & 382.362575 & 0.089 & 321.658 & 2.317 & & & $\begin{array}{c}\text { Non-equality } \\
\text { of variance }\end{array}$ \\
\hline
\end{tabular}

Table 6. Results of the second hypothesis test

\begin{tabular}{|c|c|c|c|c|c|}
\hline Std error mean & Std deviation & Mean & $\mathrm{N}$ & Smooth & \\
\hline 2.1 & 29.337 & 31.61 & 195 & 1 & Instshare \\
\hline 2.6090507 & 30.8707042 & 36.0255 & 140 & 0 & \\
\hline
\end{tabular}

Table 7. Results of the second hypothesis test

\begin{tabular}{|c|c|c|c|c|c|c|c|c|c|}
\hline \multicolumn{9}{|c|}{ T-test for equality of means } & \multicolumn{2}{c|}{$\begin{array}{c}\text { Variance } \\
\text { equality test }\end{array}$} & NOEMP \\
\hline $\begin{array}{c}\text { 95\% confidence interval } \\
\text { of the difference }\end{array}$ & $\begin{array}{c}\text { Std error } \\
\text { difference }\end{array}$ & $\begin{array}{c}\text { Mean } \\
\text { difference }\end{array}$ & Sig & df & $\mathrm{t}$ & sig & $\mathrm{f}$ & \\
\hline 10.94 & -2.13 & 3.32 & 4.41 & 0.19 & 333.00 & 1.33 & 0.21 & 1.60 & $\begin{array}{c}\text { Equality of } \\
\text { variance }\end{array}$ \\
\hline 11.00 & -2.19 & 3.35 & 4.41 & 0.19 & 290.26 & 1.32 & & & $\begin{array}{c}\text { Non-equality } \\
\text { of variance }\end{array}$ \\
\hline
\end{tabular}

Table 8 . Results of the third hypothesis test

\begin{tabular}{|c|c|c|c|c|}
\hline Std deviation & Mean & N & Smooth & \\
\hline 18.46785834 & 45.23923077 & 195 & 1 & Majorshare \\
\hline 18.8313212 & 48.152071143 & 140 & 0 & \\
\hline
\end{tabular}


Table 9. Results of the third hypothesis test

\begin{tabular}{|c|c|c|c|c|c|c|c|c|c|}
\hline \multicolumn{5}{|c|}{ T-test for equality of means } & \multicolumn{3}{c|}{$\begin{array}{c}\text { Variance } \\
\text { equality test }\end{array}$} & NOEMP \\
\hline $\begin{array}{c}95 \% \text { confidence interval } \\
\text { of the difference }\end{array}$ & $\begin{array}{c}\text { Std error } \\
\text { difference }\end{array}$ & $\begin{array}{c}\text { Mean } \\
\text { difference }\end{array}$ & Sig & df & $\mathrm{t}$ & sig & $\mathrm{f}$ & \\
\hline 1.1446764 & -6.9703577 & 2.0626757 & -2.9128407 & 0.159 & 333 & -1.412 & 0.431 & 0.623 & $\begin{array}{c}\text { Equality of } \\
\text { variance }\end{array}$ \\
\hline 1.1595699 & -6.9852513 & 2.0693055 & -2.9128407 & 0.160 & 296.085 & -1.408 & & & $\begin{array}{c}\text { Non-equality } \\
\text { of variance }\end{array}$ \\
\hline
\end{tabular}

Table 10. Results of the forth hypothesis test

\begin{tabular}{|c|c|c|c|c|c|}
\hline Std error mean & Std deviation & Mean & N & Smooth & \\
\hline 0.0075266 & 0.1051027 & 0.09996 & 195 & 1 & TD/TA \\
\hline 0.0075665 & 0.0898476 & 0.08395 & 141 & 0 & \\
\hline
\end{tabular}

Table 11. Results of the forth hypothesis test

\begin{tabular}{|c|c|c|c|c|c|c|c|c|l|}
\hline \multicolumn{5}{|c|}{ T-test for equality of means } & \multicolumn{3}{c|}{$\begin{array}{c}\text { Variance } \\
\text { equality test }\end{array}$} & NOEMP \\
\hline $\begin{array}{c}95 \% \text { confidence interval } \\
\text { of the difference }\end{array}$ & $\begin{array}{c}\text { Std error } \\
\text { difference }\end{array}$ & $\begin{array}{c}\text { Mean } \\
\text { difference }\end{array}$ & Sig & df & $\mathrm{t}$ & sig & $\mathrm{f}$ & \\
\hline 0.0375369 & 0.0055168 & 0.0109435 & 0.0160101 & 0.144 & 334 & 1.463 & 0.008 & 3.59 & $\begin{array}{c}\text { Equality of } \\
\text { variance }\end{array}$ \\
\hline 0.037006 & 0.0049858 & 0.0106725 & 0.0160101 & 0.035 & 324.704 & 2.565 & & & $\begin{array}{c}\text { Non-equality } \\
\text { of variance }\end{array}$ \\
\hline
\end{tabular}

Table 12. Results of the fifth hypothesis test

\begin{tabular}{|c|c|c|c|c|c|}
\hline Std error mean & Std deviation & Mean & N & Smooth & \\
\hline 0.0463895 & 0.6477947 & 5.729956 & 195 & 1 & Size \\
\hline 0.0480918 & 0.5710587 & 5.735073 & 141 & 0 & \\
\hline
\end{tabular}

Table 13. Results of the fifth hypothesis test

\begin{tabular}{|c|c|c|c|c|c|c|c|c|c|}
\hline \multicolumn{5}{|c|}{ T-test for equality of means } & \multicolumn{3}{c|}{$\begin{array}{c}\text { Variance } \\
\text { equality test }\end{array}$} & NOEMP \\
\hline $\begin{array}{c}\text { 95\% confidence interval } \\
\text { of the difference }\end{array}$ & $\begin{array}{c}\text { Std error } \\
\text { difference }\end{array}$ & $\begin{array}{c}\text { Mean } \\
\text { difference }\end{array}$ & Sig & df & $\mathrm{t}$ & sig & $\mathrm{f}$ & \\
\hline 0.1290067 & -0.1392416 & 0.68184 & -0.0051174 & 0.001 & 334 & -3.35 & 0.309 & 1.039 & $\begin{array}{c}\text { Equality of } \\
\text { variance }\end{array}$ \\
\hline 0.1263414 & -0.1365762 & 0.0668193 & -0.0051174 & 0.939 & 321.112 & -0.077 & & & $\begin{array}{c}\text { Non-equality } \\
\text { of variance }\end{array}$ \\
\hline
\end{tabular}

